\title{
Primer total diz artroplastisi sonrası yara yeri sorunları ve yüzeyel enfeksiyon
}

\section{Surgical site problems and superficial infection after primary total knee arthroplasty}

\author{
Bülent Özkurt, Ali Utkan
}

\author{
Sağlık Bilimleri Üniversitesi, Ankara Numune Sağlık Uygulama Merkezi, Ortopedi Anabilim Dalı, Ankara
}

\begin{abstract}
Yara yeri problemleri, total diz artroplastisi sonrası ciddi morbiditeye yol açan potansiyel olarak yıkıcı komplikasyonlardır. Ameliyat sonrası yara enfeksiyonuna yol açabilecek yara iyileşmesi problemleri, protezin enfeksiyonuna neden olabilir. Ayrıca, enfeksiyon oluşumu için cerrahi ve hastaya özgü risk faktörleri, yara yeri problemlerine yatkın olanlarla benzerdir. Yara sorunları ameliyat öncesi çok iyi bir planlama, hastaya ait risk faktörlerinin modifiye edilmesi, cilt insizyonunun çok dikkatli ve uygun yapılması, yumuşak dokuya saygılı cerrahi uygulanması gibi bazı önlemler ile sıklıkla önlenebilir. Total diz artroplastisi sonrası uzamış yara drenajı, artan ameliyat sonrası morbidite riski ile ilişkili olmasına rağmen, süreklilik kazanmış yara sızıntısının tedavisi için klinik uygulamalar önemli ölçüde değişmektedir. Yetmiş iki saatten uzun süren sızıntı artık tehlikesiz olarak değerlendirilemez ve bunlar potansiyel olarak enfekte olarak kabul edilir; beş günü geçerse yüzeyel ya da derin enfeksiyon riskini arttıracağı için ameliyathane şartlarında debridman yapılmalıdır. Yüzeyel enfeksiyon varlığı belirlendiğinde hızlı karar vererek acil tedavi protokolünü başlatmak, prognozu iyi yönde etkiler.
\end{abstract}

Anahtar sözcükler: artroplasti; diz; enfeksiyon; risk faktörleri; yara iyileşmesi problemleri; cerrahi yara enfeksiyonu

\begin{abstract}
Wound problems are potentially devastating complications following total knee arthroplasty leading to considerable morbidity. Wound healing problems that can lead to postoperative wound infection, can cause prosthesis infection. Also, surgical and patient-specific risk factors for infection formation are similar to those that predispose to wound site problems. Wound problems can be prevented by a number of measures such as a very good pre-operative planning, modifying the patient's risk factors, making the skin incision very carefully and appropriately, and performing surgery respecting the soft tissue. Although prolonged wound drainage following total knee arthroplasty has been associated with an increased risk of postoperative morbidity, clinical practice for the treatment of persistent wound leakage varies considerably. Drainage, which lasts more than seventy-two hours, can no longer be considered as safe, and are considered potentially infectious. If leakage lasts more than five days, debridement should be performed in the operating room as risk of superficial or deep infection is increased. When the presence of superficial infection is determined, initiating the emergency treatment protocol by making a quick decision affects the prognosis positively.
\end{abstract}

Key words: arthroplasty, knee; infection; risk factors; wound healing problems; surgical wound infection
T otal diz artroplastisi (TDA), ileri derecede diz osteoartrozu olan hastalarda, ağrısız fonksiyonel bir eklem elde etmek, hastanın yaşam kalitesini arttırmak amacı ile uygulanan cerrahi bir tedavi yöntemidir. ${ }^{[1-3]}$ TDA, yaklaşık beş dekaddır, zaman içinde başarı oranı yükselerek uygulanmaktadır. ${ }^{[3-5]}$ Son yıllarda triboloji, prostetik materyaller ve tasarımlarda görülen hızlı gelişmeler bu işlemin sonuçlarını mükemmele yakın hale getirmiştir. Ancak, medikal mühendislik, cerrahi tekniklerdeki ve ameliyat dönemi bakımındaki hızlı gelişmelere rağmen total diz artroplastisi uygulamalarının başarısı, cerrahın bilgisi, yeteneği, tecrübesi ve cerrahinin uygulandığı merkezin şartları ile yakından ilgili olmaya devam etmektedir. ${ }^{[4,6]}$

TDA uygun hasta seçimi, cerrahi öncesi uygun hasta eğitimi ve iyi hazırık, düzgün cerrahi yöntem, cerrahi sonrası dikkatli bakım ve rehabilitasyon kombinasyonu sağlanamaz ise yüz güldürücü olmayan sonuçlara

- Iletişim adresi: Prof. Dr. Bülent Özkurt, Martıköy Sitesi 1468. Cad. No:10, Gölbaşı, Ankara

Tel: 0532 - 5784171 e-posta: drbulentozkurt@yahoo.com

- Geliș tarihi: 19 Aralık 2018 Kabul tarihi: 19 Aralık 2018 


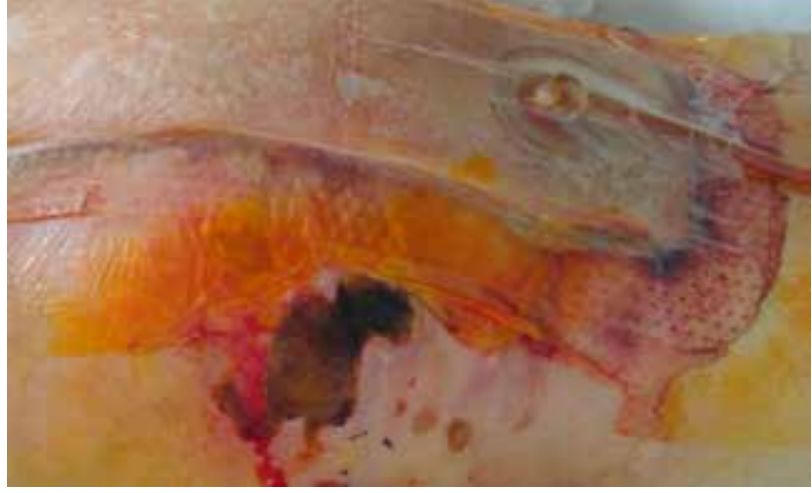

Şekil 1. Total diz artroplastisi uygulaması sonrası ciltte nekroz gelişmesi.

yol açarak hastayı ve cerrahı çok zorlu bir tedavi sürecine sokabilir. ${ }^{[2,6,7]}$ Tüm bu gereklilikler sağlandığında oluşabilmesi muhtemel çoğu komplikasyonun önüne geçilebilmekle birlikte yine de sonuçları kötü etkileyen bazı ciddi komplikasyonların ortaya çıkma riski mevcuttur. ${ }^{[2,4]}$ Farklı yayınlarda TDA sonrasında \%4-28 oranında komplikasyon bildirilmektedir. ${ }^{[2,3,8-12]}$ Oluşabilecek bu muhtemel komplikasyonları bilmek, göz önünde bulundurmak, erken tanı koyarak uygun tedaviyi hızla uygulamak sonuçları daha iyiye götürebilir.

TDA sonrası ortaya çıkabilecek birçok komplikasyon rapor edilmiştir. Bu komplikasyonlar; majör ya da minör, sistemik ya da lokal, derin ya da yüzeyel dokularla alakalı, kemik ya da yumuşak dokularla ilgili ya da prostetik implantla ilişkili olabilir. ${ }^{[2-4,12]}$ TDA gereken hastaların yaşları ve romatoid artrit gibi hastalıkları gereği birçoğunda sistemik komorbiditelerin olduğu akılda bulundurulmalıdır. ${ }^{[4]}$ Bu hastalarda sıklıkla görülen hipertansiyon, diabetes mellitus, obezite, kardiyak rahatsızlıklar, renal hastalıklar, kronik akciğer hastalıkları, hematolojik ve onkolojik hastalıklar morbiditeyi, mortaliteyi ve sistemik komplikasyonları ciddi oranda arttırmaktadır. ${ }^{[9]}$ TDA komplikasyonları arasında kardiyovasküler komplikasyonlar (tromboembolik olaylar, derin ven trombozu, pulmoner emboli, aritmi, miyokardiyal iskemi, hipotansif kriz), solunum sistemine ait komplikasyonlar (pnömoni, atelektazi, plevral effüzyon), üriner sistem enfeksiyonu, böbrek yetmezliği, hematolojik komplikasyonlar (kanama, heparin-induced trombositopeni), gastrointestinal sistem komplikasyonları (kanama, gastrik ülser, özofajit), yağ embolisi, sepsis, yüzeyel ya da derin enfeksiyon, gevşeme, bağ yetmezliği, instabilite, mediyal kollateral bağ hasarı, diz çıkığı, periprostetik kırıklar, kemik defektleri, deformite, komponent aşınması, komponent deformasyonu, komponent kırılması, komponent disosiyasyonu, ekstansör mekanizma hasarı, patellofemoral instabilite,

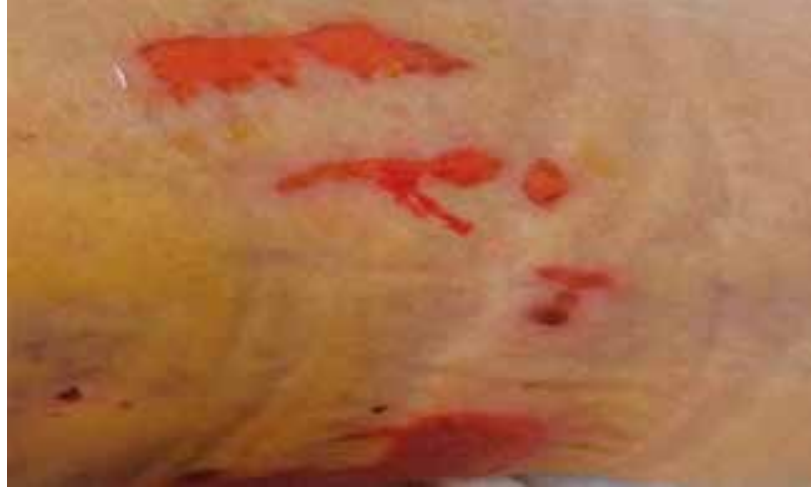

Şekil 2. Flastere bağlı ciltte bül oluşumu ve soyulması.

patellar subluksasyon, patellar dislokasyon, patellar klunk sendromu, damar-sinir hasarı, hareket kısıtlılığı, devam eden ağrı, refleks sempatik distrofi, heterotopik ossifikasyon, beklenenden fazla transfüzyon ihtiyacı ve yara yeri sorunları sayılabilir. ${ }^{[2,3,4,9,11-14]}$

Değişik yayınlarda, primer TDA sonrasında \%1-25 oranında büyük ya da küçük yara bölgesi sorunları bildirilmiştir. ${ }^{[2,9,13-16]}$ Bu sorunlar arasında yarada geç iyileşme, yara dudaklarında travmatik ya da atravmatik ayrılma, cilt nekrozu (Şekil 1), yara yerinde uzamış seröz akıntı, yüzeyel ya da derin hematom oluşumu, flaster, dikiş materyali ya da pansuman malzemelerine karşı alerjik reaksiyon (Şekil 2), ciltte bül oluşumu, yağ nekrozu, kanama, keloid oluşumu, yüzeyel ya da derin enfeksiyon sayılabilir (Tablo 1). ${ }^{[4,9,13-15,17,19]}$

Diz bölgesinde kalça ya da omuza göre kemiği ve implantı saran, eklemi çevreleyen yumuşak doku örtüsü çok daha ince olduğu için, diz bölgesi dış etkenlere karşı daha savunmasızdır. Nispeten ince olan yumuşak doku örtüsünün korunması, dolaylı olarak sağlıklı ve hızlı bir primer yara iyileşmesi protezin dış ortamla ilişkisinin bloklanması için hayati önem taşımaktadır. Bu sayede nekroz, enfeksiyon gibi ciddi komplikasyonlar en aza indirilmiş olur. Yara bölgesi sorunları diz bölgesinin belirtilen anatomik özelliğinden dolayı çok büyük komplikasyonlara yol açabileceğinden çok dikkatli olunmalıdır. Hastanın medikal durumu ve kesi bölgesi çok kapsamlı değerlendirilerek, yara iyileşmesini sekteye uğratacak tüm etkenler bertaraf edilmelidir. ${ }^{[13-15,18]}$

Yara iyileşmesini olumsuz yönde etkileyerek, yara sorunlarına yol açan etkenler olarak inflamatuvar hastalıklar, obezite, diabetes mellitus, tütün ürünleri kullanımı, kronik ilaç kullanımı (biyolojik ajanlar, immünsupresif ajanlar, steroid, yüksek doz non-steroid anti-inflamatuvar), bölgesel cilt sorunları (eski insizyon skarları, yanık sekeli, radyasyon uygulanması), 
Tablo 1. Total diz artroplastisi sonrasında görülen yara yeri problemleri

Geç yara iyileşmesi
Flaster, dikiş materyali ya da pansuman malzemelerine karşı
alerjik reaksiyon
Yağ nekrozu
Kanama
Ciltte bül oluşumu
Yara dudaklarında travmatik ayrılma
Yara dudaklarında atravmatik ayrılma
Yara yerinde uzamış seröz akıntı
Yüzeyel hematom oluşumu
Derin hematom oluşumu
Cilt nekrozu
Yüzeyel enfeksiyon
Derin enfeksiyon
Keloid oluşumu

periferik vasküler hastalıklar, malnütrisyon, $3,5 \mathrm{gr} / \mathrm{dL}$ altında albümin düzeyi, $1500 / \mathrm{mL}$ altında lenfosit sayısı, transferrin düzeyinin $200 \mathrm{mg} / \mathrm{dL}$ 'nin altında olması, hemoglobin değerinin $10 \mathrm{~g} / \mathrm{dL}$ düzeyinin altında olması sayılabilir (Tablo 2). ${ }^{[15,18-22]}$

Primer TDA sonrası yara iyileşme sorunları çok sık görülmese de, oluştuğu durumlarda yıkıcı sonuçlara yol açabilir. ${ }^{[19]}$ Yara sorunları ameliyat öncesi iyi bir planlama, hastaya ait risk faktörlerinin modifiye edilmesi, cilt insizyonunun çok dikkatli ve uygun yapılması, yumuşak dokuya saygılı cerrahi uygulanması gibi bazı önlemler ile sıklıkla önlenebilir. ${ }^{[19]}$ Tablo 2'de belirtilen albümin, transferrin, hemoglobin ve lenfosit değerlerinin normal sınırlarda tutulması ya da optimum hale getirilmesi amacı ile cerrahi öncesinde belirli bir süre anemi tedavisi, nütrisyonun kontrolü, düzenlenmesi ve desteği çok önem arz etmektedir. ${ }^{[18,19,21,23,24]}$

Diyabetik hastalarda hiperglisemi kollajen sentezinde yavaşlama ve yara direncinde azalmaya neden olurken enfeksiyona da eğilimi arttırı. ${ }^{[18,25]}$ Hastaların açlık kan şekeri düzeyinin ameliyat dönemi dönemde 200 $\mathrm{mg} / \mathrm{dL}$ 'nin altında tutulması, ameliyat öncesi HbA1c düzeyinin 6,5'in altında olması muhtemel yara yeri sorunlarını azaltacaktır. ${ }^{[25,26]}$

Vücut kitle indeksi $30 \mathrm{~kg} / \mathrm{m}^{2}$ 'nin üzerinde olan obez hastalarda normal kilolu hastalara göre enfeksiyon ve yara yeri sorunları 6,7 kat daha fazla ortaya çıkmaktadır. ${ }^{[18,22]}$ Obez hastalarda cerrahi öncesi belirli bir süre kilo kontrolü uygulaması, obeziteye yönelik cerrahi uygulamalar total diz artroplastisi
Tablo 2. Yara iyileşmesini olumsuz yönde etkileyerek yara sorunlarına yol açan faktörler

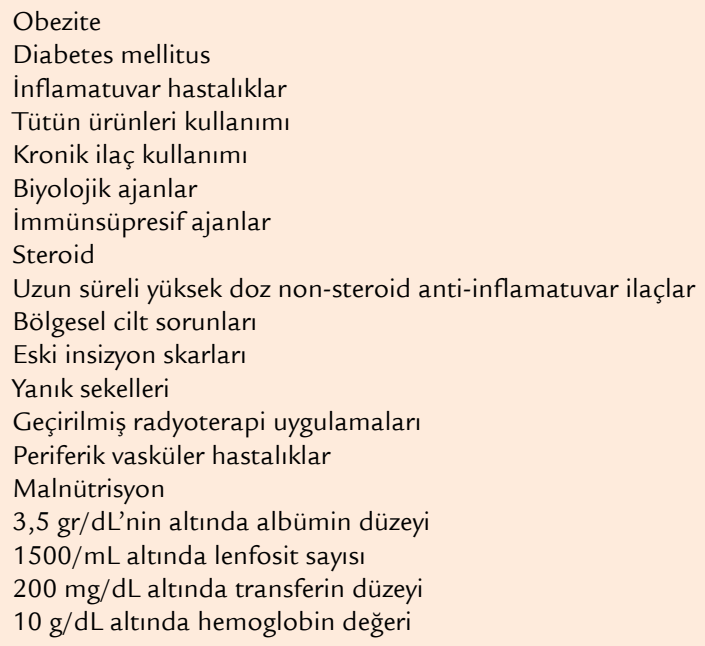

bölgesinde oluşabilecek obezite ilişkili yara açılması gibi komplikasyonları en aza indirecektir. ${ }^{[18,27]}$

Tütün mamülleri kullanan hastalarda kullanmayanlara göre TDA uygulamalarında yara yeri problemleri yaklaşık iki kat fazla ortaya çıkmaktadır. ${ }^{[18]}$ Tütün mamullerinin içeriğindeki nikotin ve yan ürünlerinin sistemik vazokonstrüktif etkisi iyi bilinmektedir. ${ }^{[18,19]}$ Yara bölgesinde nikotinin yol açtığı vazokonstrüksiyon yara bölgesine oksijen transportunu dolayısı ile hücresel seviyede metabolizmayı azaltarak yara iyileşmesini kötü yönde etkiler ve yara yeri sorunlarına neden olabilir, bu nedenle ameliyat öncesi 60 gün kadar önceden tütün mamullerinin kullanımının kesilmesi yara iyileşmesini pozitif yönde etkiler. ${ }^{[18,19]}$

Özellikle inflamatuvar eklem hastalıkları, romatoid artrite bağlı diz osteoartrozunun tedavisi için uzun süre kullanılan nonsteroid anti-inflamatuvar ilaçlar, steroid ya da biyolojik ajanların ya da başka nedenlere bağlı kullanılan immünsupresif ajanların kullanımına cerrahi öncesi belli bir süre ara verilmesi ya da doz modifikasyonu muhtemel yara yeri sorunlarını en aza indirecektir. ${ }^{[19,26]}$

Cerrahi sahada daha önceden insizyon skarının varlığında kesinin planlanması hayati önem taşır. Daha önceden var olan sorunsuz tek bir transvers insizyon skarında longitudinal orta hat (midline) kesi genellikle yara yeri sorununa yol açmayacaktır. ${ }^{[5,18]}$ Daha önceden var olan sorunsuz tek bir longitudinal insizyon varsa aynı insizyon sahası kullanılmalıdır. Eski insizyon sahası kullanılamayacak gibi ise yapılacak insizyon ile 
eski insizyon skarı arasında en az 7-8 cm mesafe bırakılmalı, ayrıca iki insizyon arasındaki cilt adacığının uzunluğu tercihen $5 \mathrm{~cm}$ 'den küçük olmalıdır. ${ }^{[5,18]}$ Şayet dizin ön bölgesinde birden çok eski longitudinal insizyon skarı varsa, dizin vasküler anatomisi göz önünde bulundurularak eski insizyon skarlarının mümkün olan en lateralde olanı kullanılmalıdır, zira diz önü cildinin beslenmesi ağırıklı olarak mediyaldeki derin perforan arterlerden sağlanmaktadır. ${ }^{[5,18]}$ Özellikle lateralde cilt altı disseksiyonundan kaçınılmalıdır. Eski insizyon skarlarının varlığında cerrahi öncesinde mutlaka plastik cerrahi konsültasyonu istenerek planlama yapılmalıdır. ${ }^{[5,18,19]}$ Nasıl insizyon yapılırsa yapılsın cildin retraktörlerle aşıı gerilmesinden kaçınılarak subfasyal kan akımı korunmalıdır. ${ }^{[18]}$

Cerrahi alanda önceden var olan yanık ya da radyoterapi sekelleri dize giriş esnasında çok büyük sorunlar oluşturabilir, cerrahi sonrasında ciddi yara yeri problemlerine neden olabilir. Bu durumlarda cerrahi öncesi planlama için mutlaka plastik cerrahların görüş ve önerileri alınmalı gerekirse cerrahi işlem esnasında plastik cerrahlardan yardım istenmelidir. Eğer yanık ya da radyoterapi sekelleri standart artrotomiye engel olacak durumda ise, cerrahi öncesinde yumuşak doku genişletme yöntemleri ile sağlıklı yumuşak doku elde edilebilir. ${ }^{[5,18,19,28]}$

Cerrahi uygulaması esnasında tüm yumuşak dokulara çok nazik davranılmalı, ek yumuşak doku hasarından kaçınılmalıdır, ayrıca yara kapatılırken yara dudaklarında ve çevre yumuşak dokularda gerginlik oluşturulmamalı, kapiller dolaşımın azalmadığından emin olunmalıdır (bu amaçla kapiller dolum testi ya da daha net olarak transkutanöz oksijen basınç yöntemleri kullanılabilir). Yara dudaklarının tam karşılıklı olarak bir araya getirildiğinden emin olunmalıdır. Primer olgularda orta hat cilt insizyonu vasküler dolaşıma en az zarar veren giriş yoludur. ${ }^{[5,19]}$ Kapsüle ulaşım esnasında cilt altı yumuşak doku mümkün olduğunca disseke edilmemeli, cildin derin fasyadan ayırılmamasına özen gösterilerek derinleşilmelidir. Hematom ya da uzamış yara drenajının oluşmasını önlemek için yara kapatılmadan önce dikkatli bir hemostaz yapılmalı, yaranın kapatılması sırasında fasya ve cilt altı yumuşak doku anatomik planda, ölü boşluklara izin vermeyecek şekilde sıkıca sütüre edilmelidir. ${ }^{[18,21]}$ Yaranın kapatılması esnasında ciltte gerginlik oluşturulmamalı; tüm katlar insizyondan önceki konumunda karşılıklı olarak dikilmelidir. ${ }^{[18]}$

Sürekli pasif hareket uygulama cihazlarının yara gerilimini arttırıp dolaşımı bozmaması amacı ile ilk başlangıçta $40^{\circ}$ ile sınırlandırılmalıdır. ${ }^{[18]}$ Cerrahi sonrası erken dönemde zorlayııı ve aşırı diz fleksiyonu ve yüksek turnike basıncı cilt hipoksisini arttırmaktadır. ${ }^{[5]}$

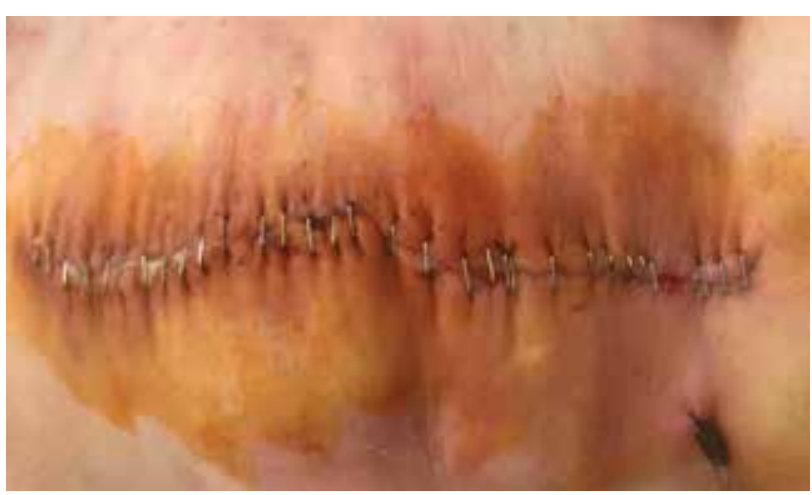

Şekil 3. Yara yerinde hematom oluşumu.

Ameliyat sonrası erken dönemde zorlayıcı rehabilitasyondan kaçınılmalıdır. ${ }^{[5,29]}$

Hematom oluşumu, enfeksiyon riskini arttırır; ayrıca ciltte gerilime neden olarak yara sorunlarına yol açabilir (Şekil 3). ${ }^{[18]}$ Bu nedenle yara yerinde hematom oluşumu önlenmelidir. Yara yerinde hematom oluşursa belirtilen komplikasyonlara yol açmadan önce ivedilikle boşaltılmalıdır. Genellikle erken dönemde iğne aspirasyonu ile kolaylıkla boşaltılabilse de, hematom organize olduktan sonra bu şansımız ortadan kalkar; bu nedenle, ameliyathanede steril şartlarda cerrahi olarak boşaltılması ve yaranın debridmanı gerekir. ${ }^{[18,19]}$

Hematomun tedavisinden ziyade oluşumunun önlenmesi çok daha maliyet-etkin ve kolay olup önem arz etmektedir. Tromboemboli profilaksisi için kullanılan medikal ajanlar insizyon sahasında kanama artışına yol açarak hematom oluşumuna neden olabilir, bu da yarada gerilmeye, ciltte beslenme bozukluğuna, bunlara bağı olarak uzamış yara drenajına dolayısıyla enfeksiyona predispozisyon yaratabilir. Yara sorununa eğilimi olduğu düşünülen hastalarda medikal profilaksinin yanı sıra mekanik profilaksi akılda tutulmalıdır. ${ }^{[19,30]}$ Ayrıca, cerrahi sonrası erken dönemde zorlayıcı rehabilitasyondan sakınmak ve sürekli pasif hareket uygulama cihazlarının daha düşük derece $\left(<40^{\circ}\right)$ ayarlanması hematom oluşum riskini azaltacaktır. ${ }^{[18]}$ Yara kapatılmadan önce dikkatli bir hemostaz yapılması, ölü boşluklara izin vermeyecek şekilde cilt altı dokuların uygun kapatılması hematom oluşumunu en aza indirecektir. Kontrendikasyonu olmayan, uygun olgularda sistemik ya da topikal traneksamik asit son yıllarda sıklıkla kullanılmaktadır. ${ }^{[18,31]}$

Yara yerinde flaster alerjisi ya da pansuman malzemelerine karşı gelişen alerjik reaksiyonların varlı̆̆ında yapışmaz (non-adherent) yarı geçirgen pansuman malzemelerinin file gibi sirküler sistemlerle tespitinin ya da poliüretan köpük kullanımının yararlı olduğu bildirilmiştir. ${ }^{[18]}$ 


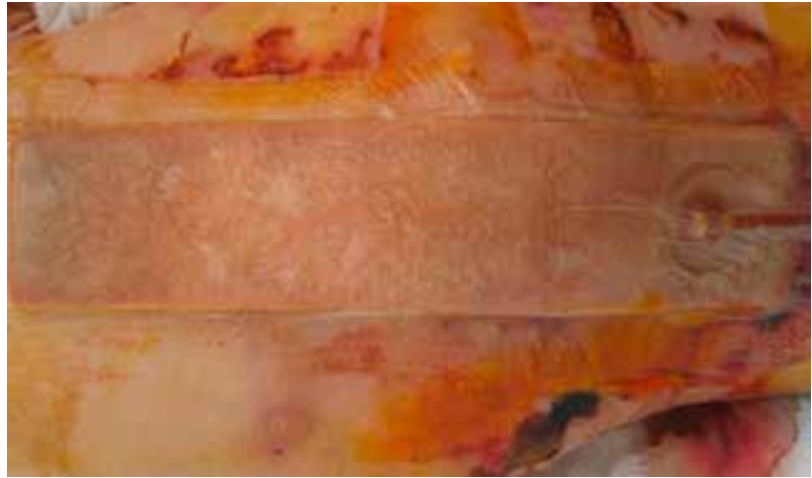

Şekil 4. Total diz artroplastisi uygulaması sonrası cillte nekroz gelişmesi sonrası yüzeyel debridman ve negatif basınçlı yara bakımı (negative pressure wound therapy) uygulanması.

Yara dudaklarında travmatik ayrılma olan, derin fasyanın sağlam olduğu hastalarda salin solüsyonu ile irrigasyon, debridman, iyi yara pansumanı, steril kapama, gerekli ise tetanoz profilaksisi ve intravenöz antibiyotik kullanımı önerilir. Ancak, antibiyotik kullanımının optimal süresi, uygulanacak optimal antibiyotik rejimi gibi sorular nedeni ile antibiyotik tedavi protokolü netlik kazanmamış olup tartışmalıdır. ${ }^{[17]}$ Derin enfeksiyon açısından yakın takip edilir. Derin enfeksiyon gelişirse ona yönelik tedaviye geçilir. Yara dudaklarında travmatik olmayan ayrılmalarda da tedavi protokolü benzerlik göstermektedir. ${ }^{[17]}$

Yara bölgesinde görülen yumuşak doku nekrozu başta enfeksiyon olmak üzere katastrofik sonuçlara neden olabilir, bu nedenle nekrozun oluşumunun önüne geçmek amacı ile yumuşak dokuya yönelik yukarıda sayılan prensiplere harfiyen uyulmalıdır (Şekil 4). Yüzeyel yumuşak doku nekrozu genellikle daha küçük girişimlerle tedavi edilebilir. Yüzeyel yumuşak doku nekrozu 3 cm'den küçükse lokal doku bakımı, vakum uygulaması, hiperbarik oksijen tedavisi ve sekonder epitelizasyon ya da kapatma ile tedavi edilebilir. ${ }^{[18,19,32]}$ Eğer yüzeyel nekroz daha büyükse ilaveten debridman ve tam kat cilt grefti ya da fasyakutanöz fleplerle tedavi gerektirir (Şekil 5 ve 6). ${ }^{[18,19,32]}$ Yumuşak doku nekrozu derin katmanlara ilerleyip tam kat ya da tama yakın yumuşak doku nekrozuna yol açmış ise, acil agresif debridman sonrası fasyalı cilt ya da kaslı cilt grefti ile kapatılmalıdır. ${ }^{[19,32,33]}$

Uzamış yara drenajı; drenaj miktarından bağımsız olarak cerrahi sonrası 48 saatten uzun süren akıntı olarak tanımlanır. ${ }^{[4]}$ Pansumanda $2 \times 2 \mathrm{~cm}$ 'den büyük ıslanma 72 saatten sonra anormal olarak kabul edilir ve yağ iskemisi, hematom, nekroz ya da kapsülün iyi kapatılmaması ile ilişkilendirilir (Şekil 7). ${ }^{[18,21,34]}$ Primer diz artroplastisi sonrası \%1-10 oranında rapor edilmiştir. ${ }^{[18]}$ Uzamış

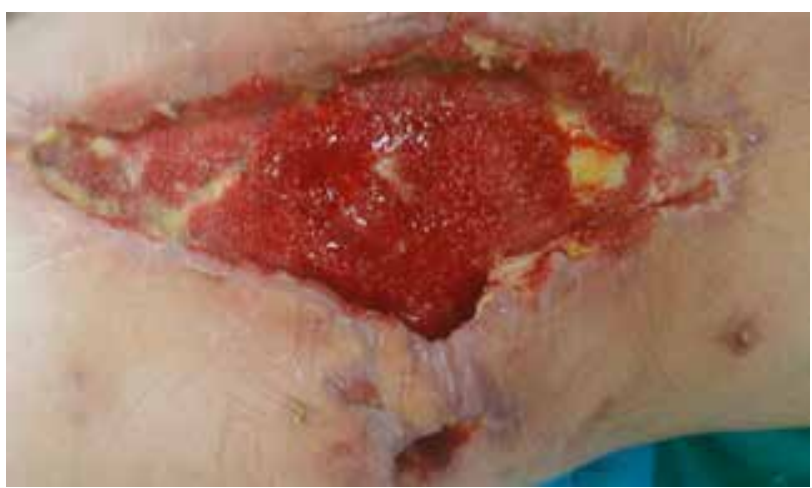

Şekil 5. Cilt nekrozu sonrasında debridman, hiperbarik oksijen ve antibiyoterapi ile derin enfeksiyon önlenmiş, yüzeyel enfeksiyon eradike edilmiş bir olgu.

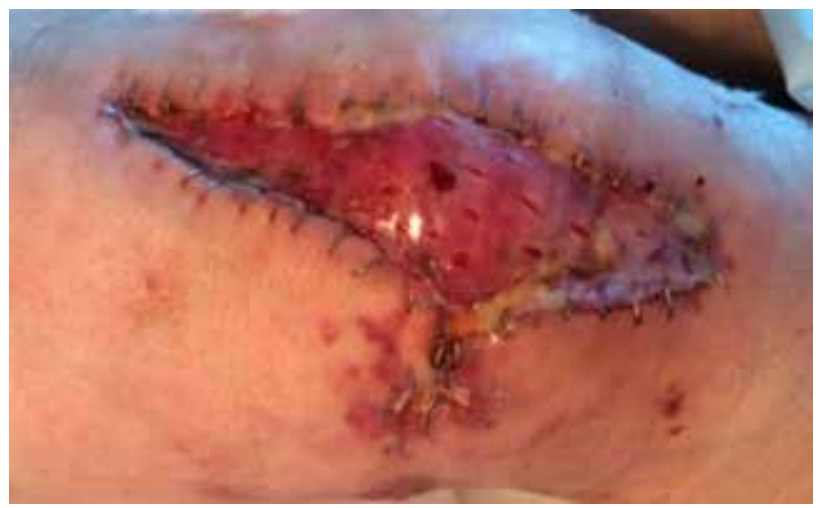

Şekil 6. Cilt nekrozu sonrasında deri grefti uygulanması.

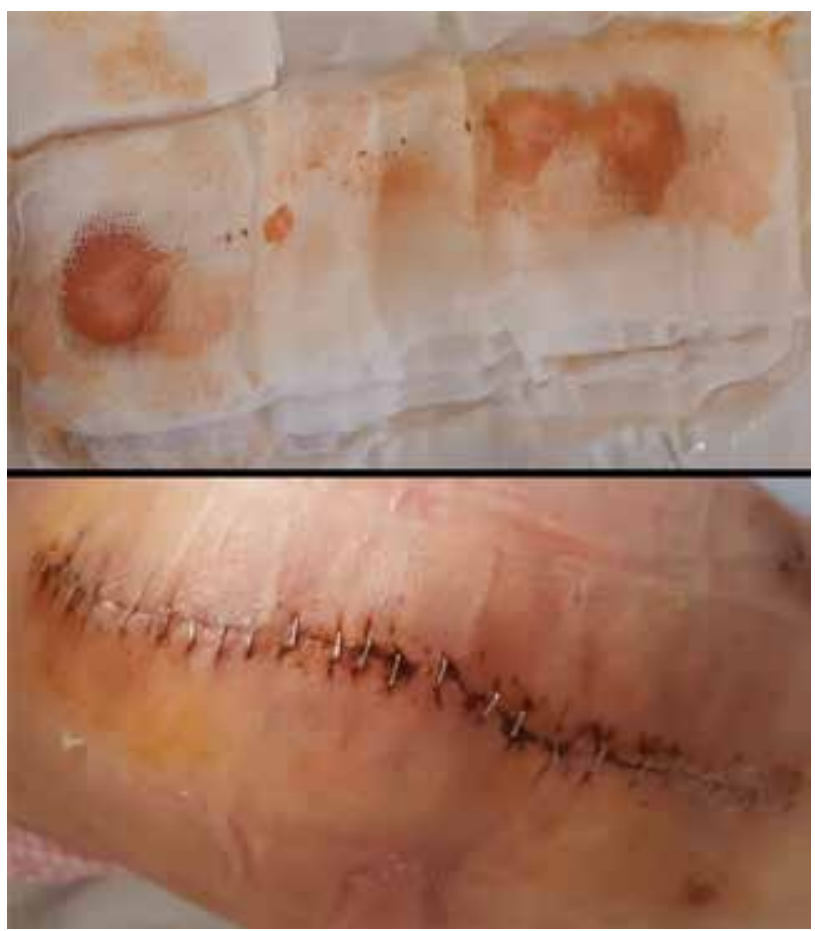

Şekil 7. Yara yerinde uzamış seroanjinöz akıntı. 


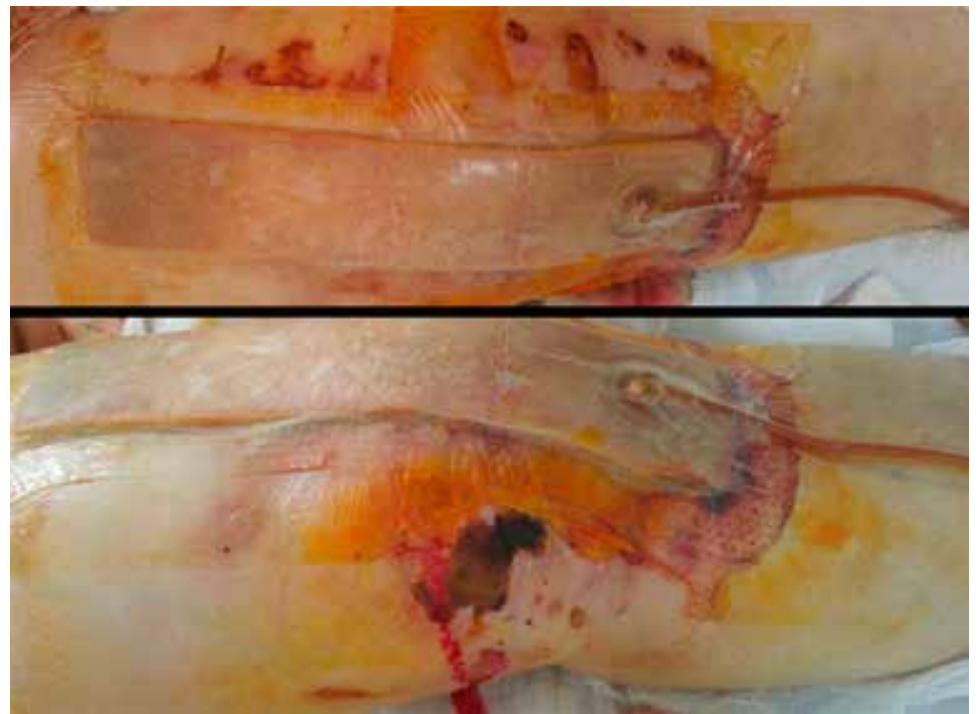

Şekil 8. Negatif basınçlı yara bakımı uygulanması.

yara drenajı yarada sorunların oluşabileceğinin ciddi bir işaretidir. ${ }^{[17,18]}$ Tedavisi için farklı görüşler olmakla birlikte, genel kabul erken evrede baskılı pansuman ve 3-5 gün immobilizasyon yönündedir. ${ }^{[5,35,36]}$ Bazı yazarlar 24-48 saatten uzun süren seröz yara drenajı varlığında negatif basınçlı yara terapisi uygulaması (NPWT) ve yapışmaz, yarı geçirgen pansuman malzemelerinin file gibi sirküler sistemlerle tespitinin yararlı olduğunu bildirmişlerdir (Şekil 8). ${ }^{18,21,37]}$ Yetmiş iki saatten uzun süren drenaj artık tehlikesiz olarak değerlendirilemez bunlar potansiyel olarak enfekte olarak kabul edilir, beş günü geçerse yüzeyel ya da derin enfeksiyon riskini arttıracağı için ameliyathane şartlarında debridman yapılmalıdır. ${ }^{[18,21,34]}$

Yumuşak doku nekrozu, uzamış yara drenajı ya da hematom varlığında antibiyotik kullanımı ile ilgili literatürde net bir görüş birliği ortaya konamamıştır. ${ }^{[17,38]}$ Antibiyotik kullanımında çok dikkatli olunmalıdır, zira gereksiz antibiyotik kullanımı bakteriyel florada değişikliklere, antibiyotik direncine yol açabilir ve derin enfeksiyon tablosunun erken teşhisini perdeleyebilir. ${ }^{[5,18,34]}$ Antibiyotik tedavisine başlanmadan önce mutlaka kan tablosunda enfeksiyon varlığına yönelik değerler ortaya konmalıdır. Hastada bulunan enfeksiyona predispozisyon yaratan diabetes mellitus, romatoid artrit, immünsupresyon gibi komorbiditeler göz önünde bulundurulmalıdır. Ayrıca, eklem aspirasyonu yapılarak eklemin durumu dokümante edilmelidir. ${ }^{[5,17,18]}$

Cerrahi alan enfeksiyonu, tüm gelişmelere ve önlemlere rağmen, total diz artroplastisi sonrası en korkulan ve katastrofik komplikasyonların başında olmaya devam etmektedir. TDA sonrasında yüzeyel ya da derin enfeksiyon zaman içinde oransal olarak azalmakla birlikte \%1-10 oranında rapor edilmektedir. ${ }^{[39-42]}$ Artroplasti sonrası enfeksiyon direkt bulaş ya da kan yolu ile ortaya çıkabilir. Direkt bulaş nedeni olarak yeterli sterlizasyon ortamı hazırlanmamış, uygun olmayan operasyon odası ve cerrahi ortam personeli, uygun olmayan cerrahi saha hazırlığı, özensiz cerrahi ekip hazırlığ ve sterilitenin yeterince önemsenmemesi, uygun hazırlanmamış cerrahi ekipman, özensiz ve uygunsuz pansuman malzemeleri ve uygulamaları, yeterince temiz olmayan hasta odaları ve aynı ortamda bulunan enfekte başka bir hasta, cerrahi alanda daha önceden enfeksiyon varlığı sayılabilir. ${ }^{[41,42]}$ Düşük enfeksiyon insidansı ameliyat odasının durumu, titiz cerrahi teknik ve asepsiye özen gösterme ile doğrudan ilişkili olduğu için, direkt bulaş nedenleri ortadan kaldırılarak enfeksiyon riski azaltılabilir. Hematojen bulaş riski ise vücutta bulunan muhtemel enfeksiyon odaklarının cerrahi öncesinde taranarak enfeksiyonun eradikasyonu ya da cerrahi sonrasında başka bölgelerde gelişen enfeksiyon odaklarının efektif ve erken tedavisi ile en aza indirilebilir. ${ }^{[41-43]}$

Total diz artroplastisi sonrası enfeksiyon oluşumu için risk faktörleri, yara yeri problemlerine predispozisyon yaratan etkenlerle benzerlik gösterir. Bu risk faktörleri hastaya bağlı, cerrahi işleme bağlı ya da ameliyat dönemi faktörler olabilir. Ameliyat öncesi uzamış hospitalizasyon, iki saatten fazla uzamış cerrahi süresi, menteşeli protez kullanımı, kan transfüzyonu, ameliyat odasında laminar akımın olmaması, erkek cinsiyet, ileri yaş, daha önceden geçirilmiş diz cerrahisi, daha 
önceden geçirilmiş diz enfeksiyonu, posttravmatik osteoartrit, hastanın düşkünlüğü, diabetes mellitus, obezite $\left(35 \mathrm{~kg} / \mathrm{m}^{2}\right.$ 'in üzerinde vücut kitle indeksi), tütün mamülleri kullanımı, intravenöz uyuşturucu kullanımı, dislipidemi, renal hastalıklar, hipertansiyon, kronik akciğer hastalıkları, hematolojik ve onkolojik hastalıklar, inflamatuvar hastalıklar, kronik ilaç kullanımı (biyolojik ajanlar, immünsupresif ajanlar, steroid, yüksek doz non-steroid anti-inflamatuvar), ASA skorunun ikinin üzerinde olması, bölgesel cilt sorunları (eski insizyon skarları, yanık sekeli, radyasyon uygulanması), periferik vasküler hastalıklar, malnütrisyon, uzamış yara drenajı, 3,5 gr/dL altında albümin düzeyi, $1500 / \mathrm{mL}$ altında lenfosit sayısı, transferrin düzeyinin $200 \mathrm{mg} /$ dL'nin altında olması, hemoglobin değerinin $10 \mathrm{~g} / \mathrm{dL}$ değerinin altında olması enfeksiyon riskini arttıran etkenler arasında sayılabilir (Tablo 3). ${ }^{[15,18-22,44-46]}$

Yüzeyel ya da derin enfeksiyon ameliyat öncesi çok iyi bir planlama, hastaya uygulanacak her türlü işleme ve ortama ait risk faktörlerinin modifiye edilmesi, çok dikkatli, cerrahi prensiplere harfiyen uyulan, yumuşak dokuya saygılı girişim uygulanması ile en aza indirilebilir. ${ }^{[19,44]}$ Yukarıda da değinildiği üzere, hastalara ait kronik sistemik hastalıkların ve medikasyonun, alışkanlıkların cerrahi öncesinde düzenlenerek kontrol altına alınması, hastanın cerrahi için optimal hale getirilmesi ve cerrahi öncesinde belirli bir süre anemi tedavisi, nütrisyonun kontrolü, düzenlenmesi ve desteği çok önem arz etmektedir. ${ }^{[18,19,21,23,24,44]}$

Total diz artroplastisi enfeksiyonlarında en sık izole edilen mikroorganizmaların başında Stafilococcus aureus ve Stafilococcus epidermidis bildirilmiştir. ${ }^{[41]}$ Stafilokok suşları üzerine en potent etkili antibiyotik olarak birinci kuşak sefalosporinler ön plana çıkmaktadır. Yara yeri enfeksiyon riskini en aza indirmek için, ameliyat dönemi dönemde birinci kuşak sefalosporinle antibiyotik profilaksisi artık rutin olarak kabul edilmiş bir protokoldür. ${ }^{[42]}$ Sefalosporin alerjisi olanlarda profilaksi için vankomisin tercih edilir. ${ }^{[44]}$ Antibiyotik profilaksisi normal şartlarda insizyondan önce en fazla iki saat içinde, tercihen anestezi indüksiyonundan 30-60 dakika öncesinde ve ilk dozu yapıldıktan sonra ameliyat sonrası dönemde 24 saat boyunca uygulanır. ${ }^{[22,44,45]}$ Yara yeri enfeksiyonu tespit edilince, intaniye konsültasyonu ile uygun antibiyotiğe erken dönemde başlanması hayati önem taşır.

Enfeksiyon varlı̆̆ında yara yerinde eritem, lokalize şişlik, pansumanda ıslanma, sistemik/lokal ısı artışı, ağrı, hassasiyet, hareket kısıtlılığı görülür (Şekil 9). Eritrosit sedimentasyon hızı, C-reaktif protein düzeyi, beyaz hücre sayı ve formülü gibi kan değerlerinde değişim olur. Eklem sıvısının mikroskopik ve biyokimyasal analizinde değişiklikler ortaya çıkar.
Tablo 3. Total diz artroplastisi sonrasında enfeksiyon oluşumu için risk faktörleri

\begin{tabular}{|c|c|}
\hline \multirow[t]{33}{*}{$\begin{array}{l}\text { Hastaya ait } \\
\text { faktörler }\end{array}$} & $\begin{array}{l}\text { Erkek cinsiyet } \\
\text { Ileri yaş }\end{array}$ \\
\hline & Daha önceden geçirilmiş diz cerrahisi \\
\hline & Daha önceden geçirilmiş diz enfeksiyonu \\
\hline & Posttravmatik osteoartroz \\
\hline & Hastanın düşkünlüğüü \\
\hline & Obezite \\
\hline & Diabetes mellitus \\
\hline & Tütün mamülleri kullanımı \\
\hline & IV uyuşturucu madde/ilaç kullanımı \\
\hline & Dislipidemi \\
\hline & Renal hastalıklar \\
\hline & Hipertansiyon \\
\hline & Kronik akciğer hastalığı \\
\hline & Hematolojik hastalıklar \\
\hline & Onkolojik hastalıklar \\
\hline & İnflamatuvar hastalıklar \\
\hline & Kronik ilaç kullanımı \\
\hline & Biyolojik ajanlar \\
\hline & İmmünsupresif ajanlar \\
\hline & Steroid \\
\hline & $\begin{array}{l}\text { Uzun süreli yüksek doz non-steroid anti- } \\
\text { inflamatuvar ilaçlar }\end{array}$ \\
\hline & ASA skorunun ikinin üzerinde olması \\
\hline & Bölgesel cilt sorunları \\
\hline & Eski insizyon skarları \\
\hline & Yanık sekelleri \\
\hline & Geçirilmiş radyoterapi uygulamaları \\
\hline & Periferik vasküler hastalıklar \\
\hline & Malnütrisyon \\
\hline & 3,5 gr/dL'nin altında albümin düzeyi \\
\hline & $1500 / \mathrm{mL}$ altında lenfosit sayısı \\
\hline & $200 \mathrm{mg} / \mathrm{dL}$ altında transferin düzeyi \\
\hline & $10 \mathrm{~g} / \mathrm{dL}$ altında hemoglobin değeri \\
\hline & Uyumsuz hasta ve hasta yakınları \\
\hline \multirow{5}{*}{$\begin{array}{l}\text { Cerrahi } \\
\text { girişime ait } \\
\text { faktörler }\end{array}$} & İki saatten fazla uzamış cerrahi süresi \\
\hline & Menteşeli protez kullanımı \\
\hline & Transfüzyon yapılması \\
\hline & $\begin{array}{l}\text { Ameliyat odasında laminar akımın olmaması gibi } \\
\text { uygunsuz ameliyathane şartları }\end{array}$ \\
\hline & $\begin{array}{l}\text { Cerrahi ekibin ve ameliyathane personelinin } \\
\text { cerrahi ve asepsi prensiplerine yeterince } \\
\text { uymaması }\end{array}$ \\
\hline \multirow{7}{*}{$\begin{array}{l}\text { Diğer } \\
\text { ameliyat } \\
\text { dönemi } \\
\text { faktörler }\end{array}$} & Ameliyat öncesi gerekli önlemlerin alınmaması \\
\hline & $\begin{array}{l}\text { Cerrahinin uygulandığı merkezin yeterli donanıma } \\
\text { ve uygun şartlara sahip olmaması }\end{array}$ \\
\hline & Ameliyat öncesi uzamış hastanede yatış süresi \\
\hline & Ameliyat sonrası uzamış hastanede yatış süresi \\
\hline & Uygun antibiyotik profilaksisinin uygulanmaması \\
\hline & Hematom oluşumu \\
\hline & Beş günden fazla uzamış yara yeri drenajı \\
\hline
\end{tabular}




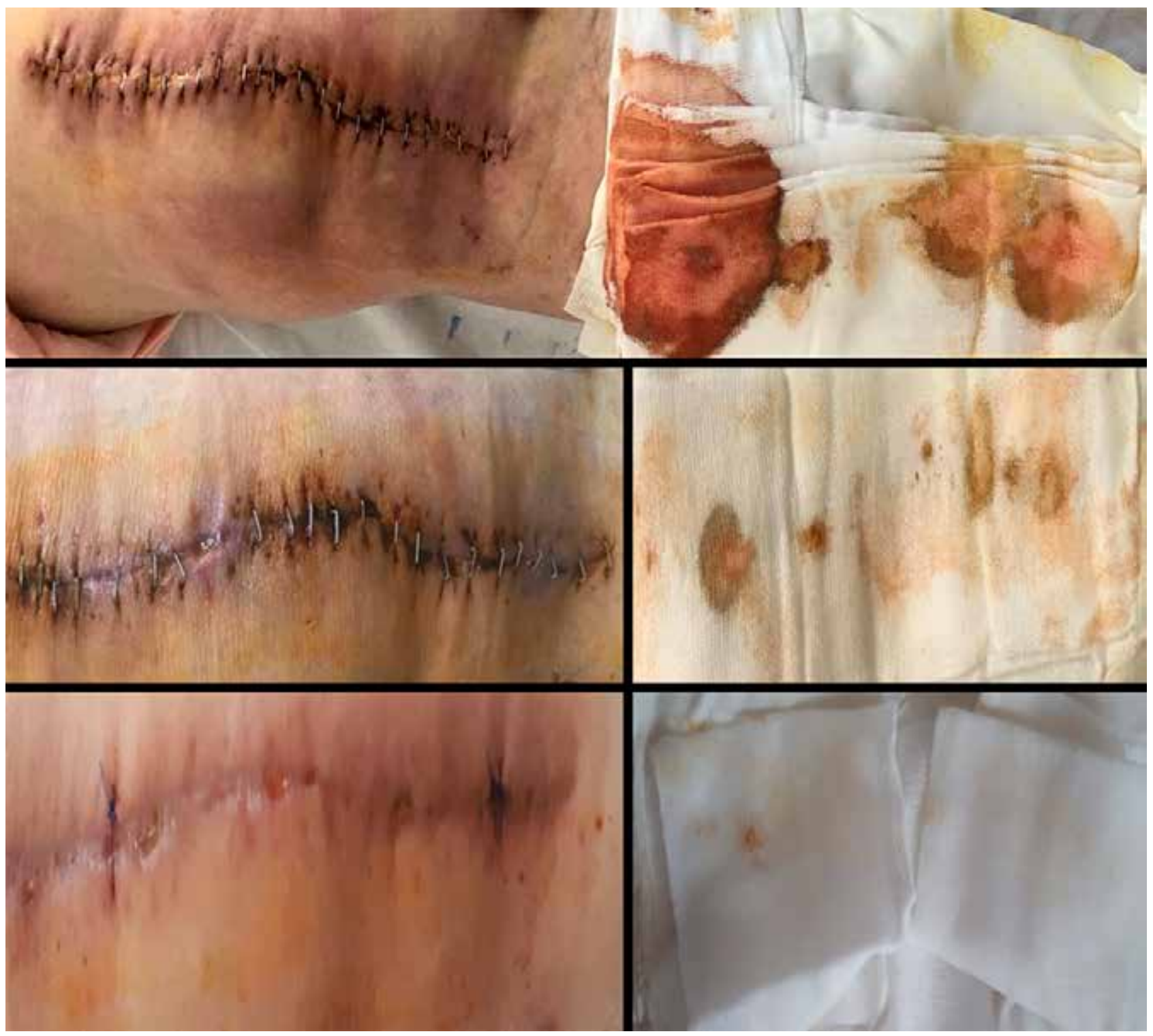

Şekil 9. Yara yerinde gelişmiş olan yüzeyel enfeksiyon, antibiyoterapi ve yara yeri bakımı ile iyileşmiş.

TDA sonrası yüzeyel enfeksiyon \%10'a kadar bildirilmiştir. ${ }^{[5,47]}$ Yüzeyel enfeksiyon tanım olarak derin fasyanın altına geçmemiş, eklem boşluğunun etkilenmediği, cilt, cilt altı ve derin fasyanın üzerinde kalan yumuşak dokuların tutulduğu enfeksiyon olarak tanımlanır. ${ }^{[17,41]}$ Yüzeyel enfeksiyon en sık ameliyat sonrası ilk 30 gün içinde ortaya çıkar. Yüzeyel yara yeri enfeksiyonu varlığında aşağıdakilerden en az biri mevcuttur: 1) insizyondan akıntı olması, 2) uygun şartlarda alınan kültürde mikroorganizma üremesi, 3) klinisyen klinik değerlendirme ile enfeksiyon varlığından şüphelenmesi, 4) olağan dışı ağrı, lokalize şişlik, eritem ya da ısı artışı olması.. ${ }^{[6]}$ Yüzeyel enfeksiyon varlığında derin enfeksiyondan farklı olarak eritrosit sedimentasyon hızında, C-reaktif protein düzeyinde ya da periferik lökosit sayımında progresif değişim olmaz, artış \%25'in altındadır. ${ }^{[5,48]}$ Ayrıca eklem aspirasyonunda sinoviyal sıvıda lökosit sayısı mililitrede 2000 hücrenin altında, polimorfonükleer hücreler \%50'nin altında olarak gözlenir. Alfa-defensin ve lökosit esteraz testleri negatiftir. ${ }^{[5,44]}$

Yüzeyel enfeksiyonun tedavisi en az derin enfeksiyonun tedavisi kadar önemli olmakla birlikte, ona göre değişiklikler gösterir. Yüzeyel enfeksiyon varlığının 
tespitinde, çok hızlı karar verilerek acilen tedavi protokolü başlatılması prognozu iyi yönde etkiler. Yüzeyel enfeksiyon varlığında yaranın durumuna ve altta yatan nedene bağlı olarak lokal yara bakımı ve oral/intravenöz antibiyotik tedavisi ya da debridman ve antibiyoterapi uygulanır. ${ }^{[44]}$ Yüzeyel enfeksiyonun hematom, uzamış yara yeri drenajı gibi altta yatan bir nedeni varsa mutlaka ortadan kaldırılmalıdır. Yarada ayrılma, nekrotik doku, devaskülarize ya da atonik doku varsa, antibiyotiğin yanı sıra debridman uygulanır. ${ }^{[44]}$ Antibiyotik kullanım süresi, intaniye önerileri doğrultusunda, enfeksiyon bulguları tamamen ortadan kalkana kadar devam eder. Antibiyoterapi olarak yara yeri kültürü alındıktan sonra ilk başta profilakside tercih edilen birinci kuşak sefalosporinler, sefalosporin alerjisi olanlarda vankomisin uygulanır, kültürde üreme olursa izole edilen mikroorganizmaya yönelik antibiyotiğe geçilir. ${ }^{[44]}$ Derin enfeksiyonun kesinlikle dışlandığı, yüzeyel enfeksiyon olduğu ortaya konan olgularda eklem kesinlikle açılmaz ve implanta dokunulmaz. Uygun hasta ve şartlarda hiperbarik oksijen tedavisinin olumlu katkısı mevcuttur. ${ }^{[49]}$

Yara yeri problemlerinin önlenmesi diz artroplastisinin başarılı sonuçları için kritik öneme sahiptir. TDA sonrası ortaya çıkabilecek yüzeyel enfeksiyon gibi yara yeri sorunları cerrahi öncesi çok iyi bir planlama ve düzenleme, cerrahi prensiplere uyma ve ameliyat sonrası iyi takip ve hızlı tedavi ile çoğunlukla önlenebilir sorunlardır. Ancak, komplikasyonları en aza indirmek için uygulanacak tüm tedbirlere rağmen yine de yumuşak doku problemleri ortaya çıkabilir. Yara yeri problemleri ortaya çıkarsa, erken tanı sonrası hızlı ve dinamik tedavi protokolleri uygulanarak derin enfeksiyon gibi daha katastrofik sorunların önüne geçilmeye çalışılmalıdır.

\section{KAYNAKLAR}

1. Yoshiya S, Kurosaka M, Kuroda R. Complications of total knee arthroplasty. Progress Clin Med JMAJ 2001;44(5):235-40.

2. Feng B, Lin J, Jin J, Qian W, Wang W, Weng XS. Thirtyday postoperative complications following primary total knee arthroplasty: A retrospective study of incidence and risk factors at a single center in China. Chin Med J (Engl) 2017;130(21):2551-6. Crossref

3. AlAzzam S, Alaskar MA, AlRabiah BK, Alhaqbani NM, AlFaleh AF, AlMugren TS, AlAzzam AS, AlQahtani HMF. Thirty-days' postoperative complications following total knee replacement in King Abdul-Aziz Medical City, Riyadh research (Alied Science). Int J Pharma Res Allied Sci 2017;7(2):67-73.

4. Parvizi J, Mui A, Purtill JJ, Sharkey PF, Hozack WJ, Rothman $\mathrm{RH}$. Total joint arthroplasty: When do fatal or near-fatal complications occur? J Bone Joint Surg Am 2007;89(1):2732. Crossref

5. Vince KG, Abdeen A. Wound problems in total knee arthroplasty. Clin Orthop Relat Res 2006;452:88-90. Crossref
6. Cheung A, Goh SK, Tang A, Keng TB. Complications of total knee arthroplasty. Curr Orthop 2008;22(4):274-83. Crossref

7. Özkurt B, Sen T, Cankaya D, Kendir S, Basarır K, Tabak Y. The medial and lateral epicondyle as a reliable landmark for intra-operative joint line determination in revision knee arthroplasty. Bone Joint Res 2016;5(7):280-6. Crossref

8. Sutton JC 3rd, Antoniou J, Epure LM, Huk OL, Zukor DJ, Bergeron SG. Hospital Discharge within 2 Days Following Total Hip or Knee Arthroplasty Does Not Increase MajorComplication and Readmission Rates. J Bone Joint Surg Am 2016;98(17):1419-28. Crossref

9. Belmont PJ Jr, Goodman GP, Waterman BR, Bader JO, Schoenfeld AJ. Thirty-day postoperative complications and mortality following total knee arthroplasty: incidence and risk factors among a national sample of 15,321 patients. J Bone Joint Surg Am 2014;96(1):20-6. Crossref

10. Zmistowski B, Restrepo C, Hess J, Adibi D, Cangoz S, Parvizi J. Unplanned readmission after total joint arthroplasty: rates, reasons, and risk factors. J Bone Joint Surg Am 2013;95(20):1869-76. Crossref

11. Minns JC, Sackley CM, Murray DM, Barker KL. Reported complications following total knee arthroplasty-Do we need to consider what, and how, to measure and classify them? J Nov Physiother 2013;3:166. Crossref

12. Healy WL, Della Valle CJ, lorio R, Berend KR, Cushner FD, Dalury DF, Lonner JH. Complications of total knee arthroplasty: standardized list and definitions of the Knee Society. Clin Orthop Relat Res 2013;471(1):215-20. Crossref

13. Berk A. Total diz protezi orta dönem sonuçları uzmanlık tezi. İstanbul: Şişli Etfal EAH; 2008. ss.34-43.

14. Yıldırım S. Total diz protezi komplikasyonları uzmanlık tezi. Konya: Selçuk Üniversitesi Meram Tıp Fakültesi; 2007. ss.23-46.

15. Alparslan AM, Atilla B. Total diz artroplastisi komplikasyonları (II). İçinde: Tandoğan R, Alpaslan AM, editörler. Diz Cerrahisi. Ankara: Haberal Vakfi; 1999. ss.373-388.

16. Pulido L, Ghanem E, Joshi A, Purtill JJ, Parvizi J. Periprosthetic joint infection: the incidence, timing, and predisposing factors. Clin Orthop Relat Res 2008;466(7):1710-5. Crossref

17. Sershon AR, Tecle N, Della Valle CJ, Levine BR, BergerRA, Nam D. The impact of an acute, traumatic wound dehiscence on clinical outcomes following primary knee arthroplasty. J Arthroplasty 2018;33(8):2613-5. Crossref

18. Simons MJ, Amin NH, Scuderi GR. Acute wound complications after total knee arthroplasty: prevention and management. J Am Acad Orthop Surg 2017;25(8):547-55. Crossref

19. Jennings MJ, Dennis AD. Wound issues after total knee arthroplasty. Duke Orthop J 2015;5(1):10-3. Crossref

20. D'Apuzzo MR, Novicoff WM, Browne JA. The John Insall Award: Morbid obesity independently impacts complications, mortality, and resource use after TKA. Clin Orthop Relat Res 2015;473(1):57-63. Crossref

21. Scuderi GR. Avoiding postoperative wound complications in total joint arthroplasty. J Arthroplasty 2018;33(10):3109-12. Crossref

22. Galat DD, McGovern SC, Larson DR, Harrington JR, Hanssen AD, Clarke HD. Surgical treatment of early wound complications following primary total knee arthroplasty. J Bone Joint Surg Am 2009;91(1):48-54. Crossref

23. Cross MB, Yi PH, Thomas CF, Garcia J, Della Valle CJ. Evaluation of malnutrition in orthopaedic surgery. J Am Acad Orthop Surg 2014;22(3):193-9. Crossref 
24. Jones RE, Russsel RD, Huo HM. Wound healing in total joint replacement. Bone Joint J 2013;95-B(II Suppl A):144-7. Crossref

25. Stryker LS, Abdel MP, Morrey ME, Morrow MM, Kor DJ, Morrey BF. Elevated postoperative blood glucose and preoperative hemoglobin $\mathrm{A} 1 \mathrm{C}$ are associated with increased wound complications following total joint arthroplasty. J Bone Joint Surg Am 2013;95(9):808-14. Crossref

26. Özkurt B. Ortopedi ve Travmatoloji'de kronik ilaç kullanımı olan hastaların perioperatif dönemde medikal tedavilerinin yönetimi. İçinde: Özkurt B, editör. Ortopedi ve Travmatoloji' de Kronik Illaç Kullanımı Olan Hastaların Perioperatif Dönemde Medikal Tedavilerinin Yönetimi. Ankara: İris Matbaası; 2016. ss.14-47.

27. Kulkarni A, Jameson SS, James P, Woodcock S, Muller S, Reed MR. Does bariatric surgery prior to lower limb joint replacement reduce complications? Surgeon 2011;9(1):1821. Crossref

28. Manifold SG, Cushner FD, Craig-Scott S, Scott WN. Longterm results of total knee arthroplasty after the use of soft tissue expanders. Clin Orthop Relat Res 2000;380:133-9. Crossref

29. Johnson DP. The effect of continuous passive motion on wound-healing and joint mobility after knee arthroplasty. J Bone Joint Surg Am 1990;72(3):421-26. Crossref

30. Parvizi J, Ghanem E, Joshi A, Sharkey PF, Hozack WJ, Rothman RH. Does "excessive" anticoagulation predispose to periprosthetic infection? J Arthroplasty 2007;22(6 Suppl 2):24-8. Crossref

31. Aguilera X, Martinez-Zapata MJ, Bosch A, Urrútia G, González JC, Jordan M, Gich I, Maymó RM, Martínez N, Monllau JC, Celaya F, Fernández JA. Efficacy and safety of fibrin glue and tranexamic acid to prevent postoperative blood loss in total knee arthroplasty: a randomized controlled clinical trial. J Bone Joint Surg Am 2013;95(22):2001-7. Crossref

32. Osei DA, Rebehn KA, Boyer MI. Soft-tissue Defects After Total Knee Arthroplasty: Management and Reconstruction. J Am Acad Orthop Surg 2016;24(11):769-79. Crossref

33. Reis MD. Skin necrosis after total knee arthroplasty. J Arthroplasty 2002;17(4 Suppl):74-7. Crossref

34. Parvizi J, Gehrke T, Chen AF. Proceedings of the international consensus on periprostethic joint infection. Bone Joint J 2013;95-B(11):1450-2. Crossref

35. Illingworth KD, Mihalko WM, Parvizi J, Sculco T, McArthur $B$, el Bitar Y, Saleh KJ. How to minimize infection and thereby maximize patient outcomes in total joint arthroplasty: a multicenter approach: AAOS exhibit selection. J Bone Joint Surg Am 2013;95(8):e50. Crossref

36. Reich MS, Ezzet KA. A nonsurgical protocol for management of postarthroplasty wound drainage. Arthroplasty Today 2018;4(1):71-3. Crossref

37. Pachowsky M, Gusinde J, Klein A, Lehrl S, Schulz-Drost S, Schlechtweg P, Pauser J, Gelse K, Brem MH. Negative pressure wound therapy to prevent seromas and treat surgical incisions after total hip arthroplasty. Int Orthop 2012;36(4):719-22. Crossref
38. Wagenaar FC, Löwik CAM, Stevens M, Bulstra SK, Pronk $\mathrm{Y}$, van den Akker-Scheek I, Wouthuyzen-Bakker M, Nelissen $\mathrm{RGHH}$, Poolman RW, van der Weegen W, Jutte PC. Managing persistent wound leakage after total knee and hip arthroplasty. Results of a nationwide survey among Dutch orthopaedic surgeons. J Bone Jt Infect 2017;2(4):202-7. Crossref

39. Crockarell JR, Guyton JL. Arthroplasty of the knee. In: Canale TS, Beaty JH, editors. Campbell's Operative Orthopaedics, 11th ed. Philadelphia: Mosby Inc., Elsevier; 2008. pp.241-311.

40. Krebs VE, Malkani AL, Ulrich SD, Beckstein D, Abolghasemian M, Springer BD, Samujh C. Complications of knee arthroplasty. In: Mont AM, Tanzer M, editors. Ortopaedic Knowledge Update 5, Hip and Knee Reconstruction. Rosemont, IL; American Academy of Orthopaedic Surgeons; 2017. pp.233-66.

41. Bilgen S, Eken G. Surgical site infection after total knee arthroplasty: A descriptive study. Int Multispecialty J Health 2016;2(2):1-8.

42. Ashraf I, Mohib Y, Hasan O, Malik A, Ahmad K, Noordin $S$. Surgical site infection surveillance following total knee arthroplasty: Tertiary care hospital experience. Ann Med Surg (Lond) 2018;31:14-6. Crossref

43. Özkurt B. Preventing late hematogenous periprosthetic infections. TOTBID Dergisi 2016;15(2):154-7. Crossref

44. Teo BJX, Yeo W, Chong HC, Tan AHC. Surgical site infection after primary total knee arthroplasty is associated with a longer duration of surgery. J Orthop Surg (Hong Kong) 201;26(2):2309499018785647. Crossref

45. Hijaz-Gomez Al, Lucas WC, Chea-Garcia A, Martinez-Martin J, Fahandezh-Saddi H, Gil-De-Miguel A, Duran-Poveda M, Rodriguez-Caravaca G. Surgical site infection incidence and risk factors in knee arthroplasty: A 9-year prospective cohort study at a university teaching hospital in Spain. Am J Infec Contr 2018;46(12):1335-40. Crossref

46. Saleh K, Olson M, Resig S, Bershadsky B, Kuskowski M, Gioe $\mathrm{T}$, Robinson H, Schmidt R, McElfresh E. Predictors of wound infection in hip and knee joint replacement: results from a 20 year surveillance program. J Orthop Res 2002;20(3):506-15. Crossref

47. Gaine WJ, Ramamohan NA, Hussein NA, Hullin MG, McCreath SW. Wound infection in hip and knee arthroplasty. J Bone Joint Surg Br 2000;82(4):561-5. Crossref

48. Löwik CAM, Wagenaar FC, van der Weegen W, Poolman RW, Nelissen RGHH, Bulstra SK, Pronk Y, Vermeulen KM, Wouthuyzen-Bakker $M$, van den Akker-Scheek I, Stevens $\mathrm{M}$, Jutte PC; LEAK study group. LEAK study: design of a nationwide randomised controlled trial to find the best way to treat wound leakage after primary hip and knee arthroplasty. BMJ Open 2017;7(12):e018673. Crossref

49. Çimşit M. Osteomiyelit ve hiperbarik oksijen tedavisi. İçinde: Çimşit M, editör. Hiperbarik Tıp. Ankara: Eflatun Kitabevi; 2009. ss.241-55. 